views for centuries, but they still persist, with geologists continuing to refute them.

If contemporary lists of the greatest scientists feature a geologist at all, it is usually Lyell, a central figure in Worlds Before Adam. Lyell intended the title of his great multi-volume opus Principles of Geology (first published in 1830-1833) to recall Isaac Newton's Principia. He sought to recast geology on firm foundations, just as Newton had done for physics. Following his geologist contemporaries and predecessors, Lyell used the understanding of present-day causes to interpret the deep past - a principle termed actualism. Rudwick explains that Lyell's excellent descriptions of current geological processes, embellished with observations from his own geological excursions, derived from an original listing by the eighteenth-century German scholar Karl Ernst Adolf von Hoff. Lyell greatly extended the actualistic method by making pronouncements about how the complex geological processes of the past occurred through the progressive action of small-scale procedures that were still in operation, and by prescribing how geologists should reason about these past processes.

Rudwick shows that Lyell's ideas met with almost universal criticism. This was not caused by his advocacy of actualism, which was widely used, nor was any serious denunciation forthcoming from the biblical literalists, who were considered anti-scientific by Lyell and by his critics. Instead, the geological facts themselves seemed contrary to Lyell's vision of uniform action by small-scale processes operating over a long time. Examples include evidence for sudden mass extinctions from records in various 'bone caves', the existence of huge blocks sitting erratically out of geological place in the Alps and northern Europe, and deep U-shaped valleys containing streams too small to account for their excavation. Lyell's critics held that one should inquire into nature through evidence, rather than through privileged reasoning.

The great Cambridge polymath William Whewell named the two sides in the debate. Lyell's advocates he labelled 'uniformitarians'; their opponents he called 'catastrophists'. It is an irony of subsequent developments in geology, and a testimony to the success of Lyell's advocacy, that catastrophism came to be regarded as unconventional. This perverted Whewell's original intention, which was to show that the uniformitarians and Lyell were extreme in thinking that geologists should say in advance how nature works, through slow and uniform processes, before interpreting the evidence.

Worlds Before Adam concludes with the development of glacial theory, popularized in the nineteenth century by Cuvier's disciple Louis Agassiz, perhaps the greatest of the catastrophists. Agassiz's theory of the great spread of ice sheets during relatively recent geological time gained rapid acceptance among catastrophists because it accounted for many anomalous features originally ascribed to huge floods or tsunamis. However, Lyell resisted, remaining true to his epistemological project.

As we enter an era of global crises about water, energy and the environment, and as we seek to understand the development of our species among others in one corner of the Universe, geologists' perspectives give a means for both understanding and coping. In showing how these perspectives arose, Rudwick highlights an underappreciated, glorious advance in human thought, the documentation of which is a rather glorious achievement in itself

Victor R. Baker is Regents' Professor of Hydrology and Water Resources, Planetary Sciences and Geosciences at the University of Arizona, Tucson, Arizona 85721, USA, and ex-president of the Geological Society of America.

e-mail:baker@hwr.arizona.edu

\title{
Romance among robots
}

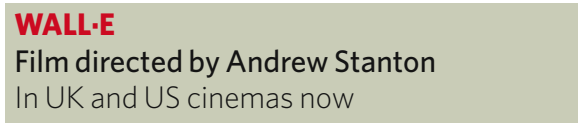

A few years ago, at the Massachusetts Institute of Technology's artificial intelligence lab, I met an android. Her conversation was perfunctory, mostly simple responses to my equally simple words, but her eyes, widening, narrowing and subtly changing angle, made a genuine emotional connection. That robot had me at "Hello". So it is with WALL.E (pictured), the eponymous hero of Disney-Pixar's new animated film. Part Mars rover, part Andy Hardy, WALL·E charms us every step of the way as he saves a planet while pursuing chaste robotic love.

The movie opens on a bleak future, reminiscent of films by director Ridley Scott at his dystopian best. Earth, abused and then abandoned by a population that never heeded $\mathrm{Al}$ Gore, lies grey and silent beneath the refuse of civilization. Punctuating the stillness is a small buzz of activity. WALL·E, a computerized rubbish compactor, perhaps descended from those robotic vacuum cleaners, dutifully pursues work he was programmed to do hundreds of years earlier, before humans gave up on the

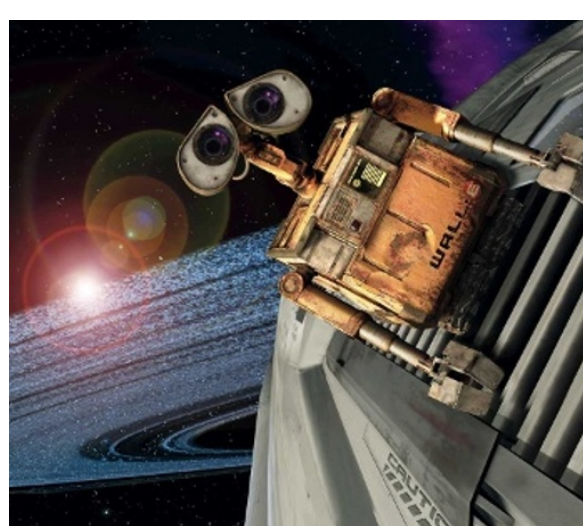

dream of refurbishing the planet. It's not a bad existence, but as he considers the oddments he has scavenged over time, particularly an old video tape of the film Hello, Dolly!, WALL·E recognizes that something is missing. That something soon materializes in the form of a robotic scout, sent to Earth to search for signs of photosynthesis. The scout is named EVE and ... well, you can see where all this leads.

Movie buffs will enjoy WALL.E's film references - from 2001: A Space Odyssey (of course) to Modern Times. Science nerds will appreciate how both the story and the animation are informed by NASA and research into artificial intelligence. Pixar animators have mastered the literature on non-verbal communication; they have studied in detail the workings of robots from Mars rovers to assembly lines, and have internalized the stunning images from the Hubble and Spitzer space telescopes.

The animation in WALL E $E$ is astonishing, but Pixar recognized long ago that technology alone does not fill cinemas. Stories do, and WALL E Es creators are master storytellers. Sci-fi master Robert Heinlein maintained that there are only three plots in science fiction. All figure here: a sweet love story, the triumph of plucky stowaways over a power-hungry computer (remember HAL?), and a plea for planetary redemption. Moreover, the movie is funny. Eight-year-olds and octogenarians alike laughed throughout the screening, usually at the same time.

So, for animated sci-fi that honours both the science and the fiction, steal away to WALL.E. And, if you work at NASA's Jet Propulsion Laboratory in California, go and see it twice. When a future Mars rover angles its soulful head-lamps while asking for more funding, who at NASA will be able to refuse?

Andrew H. Knoll is Fisher Professor of Natural History at Harvard University, Cambridge,

Massachusetts, and a member of NASA's Mars

Exploration Rover science team.

e-mail:aknoll@fas.harvard.edu 